Historic, Archive Document

Do not assume content reflects current scientific knowledge, policies, or practices. 


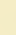




\section{THE GLEN ROAD IRIS GARDENS}

WELLESLEY FARMS, 95, MASS.

We are glad to announce that our stock permits of a reduction of prices on many varieties in our current lisis. It will be another year before a new catalog is issued but we will willingly replace your copy on request. There is a discount of 20 per cent. on all orders of over $\$ 100.00$ and of 10 per cent. on orders over $\$ 50.00$.

Our gardens are full of color from early May to mid-June. We look forward to the first blooms of hundreds of seedlings and the latest of the foreign introductions. A visit from you would be a pleasure and we should also appreciate an opportunity to rectify any error of nomenclature which may, despite our care, have crept into our orders.

AFTERGLOW

ANNE LESLIE

CHANGE OF PRICE FOR 1920 DELIVERY

BASHI-BAZOUK

BLUETT

B. Y. MORRISON

DEMURE.

*ELINOR

*EMPIRE

HOPE

JENNETT DEAN (NOTT FOR SALE)

*LATRINKA

*LUGARDA

MAGNATE

MANDELAY

MEDALLION

MERLIN

MME. CHERI

PALAUREA

PRESTIGE

PURPLE-AND-GOLD

$\$ 3.00$
2.00
3.00
1.50
3.00
1.00
2.50
2.50
1.50
2.50

.75
2.50
1.50
.75
4.00
6.00
2.00
1.50
1.00

3.00

2.00

3.00
1.50

3.00

1.00

2.50

1.50

2.50

.75

1.50

.75

4.00

2.00

1.50

1.00

\section{QUEEN CATERINA}

RAKAN

RANGOON

SARABANDE

SHEKINAH

STANLEY H. WHITE

TANGIERS

*THE SCREAM

WHIFFENPOOF

STANDARD VARIETIES

ARCHEVEOUE

EDOUARD MICHEL

ELDORADO

ISOLINE

LENT A. WILLIAMSON

MONSIGNOR
$\$ 5.00$

.75

1.00

2.00

15.00

5.00

5.00

1.00
* Slow of growth or variable and subject to further trial.

CORDON BLEU-A deep, unusually blue-toned purple self with smooth, spreading falls. Rich in garden effect. 27 in.

KOYA-Delightfully ruffled segments, the standards arched and resolute, the falls drooping; color a rich, bright purple, the channeled haft conspicuously veined on white. $3 \mathrm{ft}$.

NAUSHON-- Well-branched stalks, the flower rather pointed, the broad, ruffled petals with a texture slightly creped, the color mauve and pansy violet, it makes a heavy flowered clump. 30 in.

For six years these have been among the "try outs", each year they seemed more worthy of general use. They may prove as useful in your garden as they have in ours. 
